\title{
Vasilii Petrov and the Poetics of Patronage
}

\author{
Luba Golburt \\ University of California, Berkeley \\ lgolburt@berkeley.edu
}

\begin{abstract}
:
This article seeks to bridge the gap between sociohistorical and aesthetic readings of Russian occasional verse by arguing that patronage itself can be seen as engendering its own poetics. The author focuses on hitherto unanalyzed features of Vasilii Petrov's lyrics addressed to various patrons. The close readings of Petrov's odes and epistles call attention to the poet's coordinating syntax as structuring the subordinative relationships between poet and patron, and articulating discourses of friendship, community, and the public, of civic virtue, and of social and lyric interdependence. The essay ultimately arrives at a definition of the poetics of patronage, in which the poet claims agency without insisting on his autonomy (as would his successors in the Romantic period), and in which the lyric voice relies upon an other, drawing inspiration from conditions of relationship rather than isolation.
\end{abstract}

Keywords:

Vasilii Petrov, patronage, poetics, panegyric, ode, Pindar, Horace, lyric subjectivity, friendship, power, Romanticism, pre-Romanticism, literary history

Eighteenth-century Russian panegyric poetry is widely seen as hard to appreciate on its artistic merits; perhaps most incriminating in this regard is its open propagation of patronal rhetoric. As a result, the rare moments of aesthetic pleasure derived from the genre come specifically from its most aberrant manifestations, such as Derzhavin's "Felitsa," a text written for no official occasion or commission, and indeed famous for stretching the ode's generic conventions. Such largely exceptional texts thus paradoxically emerge as the odic genre's most enduring representatives, read against the grain of the genre's overall panegyric purpose, and with an uneasy acknowledgment of its underlying system of exchange between author and high-placed reader. The odic genre implicitly stands, then, as one whose expressive potential is ontologically constrained or compromised by the sociopolitical conditions of its production and circulation; whose makeup is necessarily uneven, at best "1/4 gold, 3/4 lead," as Alexander Pushkin described Gavrila Derzhavin's legacy. ${ }^{1}$

The prevailing bias that the Russian ode is deficient in aesthetic value, and implicated in a system of exchange corrupting to poetic "purity," is in large part owed to lasting transformations wrought by the Romantics in conceptions of literary value and creativity. ${ }^{2}$ Romanticism and post-Romanticism conferred literary legitimacy on those

I am thankful to Joachim Klein, Boris Maslov, Ernest Zitser, and Vivliofika's anonymous reviewers for their feedback and to Avram Brown for his editorial assistance.

${ }^{1}$ A. S. Pushkin, Polnoe sobranie sochinenii $v$ desiati tomakh (Moscow: Izd-vo Akademii nauk SSSR, 1949), 9: 158.

${ }^{2}$ Robert Folkenflik claims that, at least in the case of English lyric, the divestment from patronage occurred independently of and prior to Romanticism. See Robert Folkenflik, "Patronage and the Poet-Hero," Huntington Library Quarterly 48, no. 4 (Autumn 1985): 363-79, here 375. 
sources of inspiration immanent in poetic craft itself, or on an electedness understood as more or less divinely-ordained. This stance ultimately delegitimized earlier poetry, which had often laid no claim to prophetic license, and responded quite comfortably (if not altogether unreflexively) to commission from worldly authorities. ${ }^{3}$ Just as the subsequent evolution of the Russian literary language rendered eighteenth-century stylistic experimentation both a precursor and a discarded alternative to the post-Pushkin poetic idiom, the vexed history of modern Russian literature's resistance to the state has likewise charged all attempts at symbiotic contact between poetry and power with the crimes of inauthenticity and mercenarism, or at best relegated them to the domain of premodern culture. ${ }^{4}$ The resulting bias may not be shared by devoted students of the eighteenthcentury Russian ode, but it does nevertheless characterize the broader subsequent reception of the genre as largely unreadable, or not worth reading except in the context of expert knowledge of the texts' sociopolitical circumstances.

This essay aims to bridge the gap between sociohistorical and aesthetic/formal readings of the eighteenth-century ode by arguing that the very practice of patronage engenders stylistic innovations and motivates distinctive structures of the I/thou relationship and lyric address. How do texts predating Romantic conceptions of artistic autonomy, and indeed written in a culture that was fundamentally shaped by the court and its concomitant hierarchical worldview, conceive of their very placement within a complex system of interdependencies as a form of creative endowment?

Investigating this question, we would be hard pressed to find a more fitting oeuvre to examine than that of Vasilii Petrov (1736-99). As a lifelong friend and protégé of Prince Grigorii Potemkin (from 1761 on) and beneficiary of other noblemen's favors, a tutorcompanion to a young Russian aristocrat sojourning in England (1772-74), and, perhaps most notably, as a translator at Catherine's privy cabinet and royal reader and librarian

\footnotetext{
${ }^{3}$ A more thorough history of the ode's delegitimation would have to attend to the restructuring in late eighteenth-century aesthetics of the cultural field as comprising practical crafts and fine arts, and to the legacy in the nineteenth century of the Kantian concept of disinterestedness. For a brief history of these issues and a statement of their modern application in aesthetic theory, see Norman Kreitman, "The Varieties of Aesthetic Disinterestedness," Contemporary Aesthetics 4 (2006), URL: http://www.contempaesthetics.org/newvolume/pages/article.php?articleID=390, accessed 17 January 2015. Particularly illuminating for the purposes of my essay is David Wellbery's analysis of Romantic poetic theory's delegitimation of rhetoric, the pragmatism of which, in particular, was seen as objectionable. See David Wellbery, "The Transformation of Rhetoric," in The Cambridge History of Literary Criticism, ed. Marshall Brown (Cambridge: Cambridge University Press, 2000), 5: 185-202.

${ }^{4}$ Witness, for instance, as even so dedicated a scholar and commentator on the eighteenth century as P. P. Pekarskii dismisses the ode precisely on ethical grounds, rejecting out of hand the very idea of reading the genre aesthetically: "Panegyrics and odes hardly belong to the study of serious literature; at best they can serve as material to clarify the moral side of this famous epoch.... An analysis of panegyrics and odes from this perspective could even be instructive, but it is doubtful that a scholar could be found who would have the strength to take on the dismal labor of writing a history of the moral debasement of human dignity." P. P. Pekarskii, Nauka i literatura v Rossii pri Petre Velikom, 2 vols. (St. Petersburg: Obshchestvennaia pol'za, 1862), $1: 362-63$.
} 
(1768-8o), Petrov had ample and varied experience with noble and monarchal patronage. ${ }^{5}$ As a graduate of Moscow's Slavic-Greek-Latin Academy, a close acquaintance of several English writers, and one of eighteenth-century Russia's most learned poets, Petrov was exceptionally attuned to both the Classical and contemporary European literary traditions: hence to the enduring and metamorphosing institutions of patronage on which these traditions depended; and, conversely, to what one scholar of the late eighteenth and early nineteenth centuries has dubbed the "consecration" of the writer in the West, the ongoing writerly professionalization and the emergence, particularly in England, of a self-sustaining literary market. ${ }^{6}$ Far from attempting to rectify Petrov's lasting and in part self-propagated reputation as Catherine's "pocket poet" (karmannyi stikhotvorets), this essay draws attention to the sophisticated refinement of this role as performed in his panegyric corpus. ${ }^{7}$

The majority of Petrov's verse comprises odes and epistles marking some occasion or directed at an addressee, possessed more often than not of exalted social standing. ${ }^{8}$ These texts repeatedly contemplate and negotiate, from within the patron-client framework, conditions of poetic dialogue, address, subjectivity, and readership, as well as poetry's capacity for reflecting and modeling the social world. ${ }^{9}$ The discourses of

\footnotetext{
${ }^{5}$ The most comprehensive treatment to date of Petrov's immersion in the patronage paradigm, albeit focused specifically on the lyrics addressed to Potemkin, is Ulrike Jekutsch, "Vasilii Petrov i Grigorii A. Potemkin. Ob otnosheniiakh poeta i pokrovitelia," Russian Literature 75, no. 1-4 (2014): 219-48.

${ }^{6}$ Paul Bénichou, The Consecration of the Writer, 1750-1830 (Lincoln, NE: The University of Nebraska Press, 1999). On Petrov's cultural contacts with English contemporaries, see A. G. Cross, "Vasilii Petrov v Anglii (1772-1774)," XVIII vek, vyp. 11 (1976), 229-46.

${ }^{7}$ On Petrov's self-presentation and reputation, see I. Shliapkin, "Vasilii Petrovich Petrov, 'karmannyi' stikhotvorets Ekateriny II. (1736-1799). (Po novym dannym)," Istoricheskii vestnik 23, no. 11 (1885): 381-405. More recently, Nadezhda Alekseeva has offered a convincing interpretation of both Petrov's poor reputation and the learned sophistication of his work, reading the two phenomena as interconnected. See Nadezhda Alekseeva, "Torzhestvennye ody Petrova," in Russkaia oda: Razvitie odicheskoi formy v XVII-XVIII vekakh (St. Petersburg: Nauka, 2005), 275-308. Alekseeva also notes (300) that Petrov was one of the first Russian ode-writers to address (in his 1771 ode to G. G. Orlov) a nobleman rather than member of the royal family, an observation essential for understanding Petrov's patronal poetic corpus as distinctive, capacious, and diverse. Alekseeva's account serves as a corrective to the received perception (e.g., per G. A. Gukovskii, Russkaia literatura XVIII veka [Moscow: Aspekt, 1999], 245-49) that Petrov's admitted flattery of the powerful necessarily renders his corpus devoid of aesthetic value. Evgeny Bershtein has also made a case for reading Russian occasional verse, and that of Vasilii Petrov specifically, for its stylistic innovations. See Evgeny Bershtein, "The Solemn Ode in the Age of Catherine: Its Poetics and Social Function," in Poetics of the Text: Essays to Celebrate Twenty Years of the Neo-Formalist Circle, ed. Joe Andrew (Amsterdam: Rodopi, 1992), 79-90.

${ }^{8}$ The edition I consulted for this article is the three-volume Sochineniia V. Petrova (St. Petersburg: Meditsinskaia tipografiia, 1811); of the sixty-nine texts collected therein, roughly $90 \%$ fall under this broad description, although this estimate does not take into account Petrov's translations. For a more detailed statistical analysis, see Jekutsch, "Vasilii Petrov i Grigorii A. Potemkin," 226.

${ }^{9}$ In recent scholarship (Andrei Zorin, Kormia dvuglavogo orla: Literatura i gosudarstvennaia ideologiia $v$ Rossii v poslednei treti XVIII-pervoi treti XIX veka [Moscow: Novoe literaturnoe obozrenie, 2001], 65-94; Vera Proskurina, Creating the Empress: Politics and Poetry in the Age of Catherine II [Boston: Academic Studies Press, 2011], 26 et passim), Petrov has been read most productively as responding to and poetically articulating Catherine II's political projects; my reading, though appreciative of this trend, attempts a different approach to Petrov as an exponent of power.
} 
friendship and service that Petrov elaborates in lyrics addressed to various patrons throughout his career cast him as a poet in dialogue with his heroes and, at the same time, with an extensive panegyric tradition. The hero-patron is conceived in turn as both a superior figure of power and prowess and, on numerous occasions, a genuinely affective interlocutor, an engaged rather than merely pro forma recipient of the poetic word.

It might be tempting to dismiss Petrov's construction of affinity as a matter of attending to the purely rhetorical requirements of the Classicist panegyric; or on the other hand, to take it at face value, if also rather reductively, as a reflex of the emergent Sentimentalist worldview. A more nuanced approach, I suggest, would read Petrov's poetry as profoundly oriented toward the neo-Classical revival not only of Pindaric and Horatian odic forms, but also of the poet-addressee relationships these forms were originally summoned to articulate. ${ }^{10}$ It is in its very orientation toward literary precedent that Petrov's lyric absorbs the existing social circumstances of its creation, circulation, and reception into a particular vision of affective poet-patron relations, one interpretable, and in fact legitimated, as creatively inherited from a literary past and at the same time generatively innovative.

\section{Benefaction and the Body Heroic}

Any poetic dialogue with a patron involves more than two parties, more than speaker and addressee. The patron's charity, one of the oft-invoked grounds for panegyric praise, rarely benefits the poet alone. In fact, its abundance and broad distribution justify the poet's "sweet talk" as a voice of many. The poetic utterance is thus produced in awareness of the social realm, the multitude who, were they to speak, would do so in unison with the poet; were they to hear the ode, would recognize the poet's sentiments as their own. The poet's voice, then, while certainly imbued with individual artistic agency, emerges as if from a collective murmur; and the ode's reader, while focalized primarily as the patron-hero, is also always an imagined collective of those marveling at the hero's feats. The ode's multivoicedness and multidirectedness manifest themselves in the grammatical instability of its deictic references: from one passage to the next, the patron may be addressed in the second person but described in the third, and the same shifting point of view characterizes the speaker's stance vis-a-vis the multitude. The supple grammar - and Petrov is a master rhetorician - communicates, without overstating, the panegyrist's pragmatic negotiations.

What precisely is the place of the collective, whether confronted in the second person or gestured at in the third, in a poem that stages a conversation between poet and patron? Scholars of Pindar have described the poet's work in narrating and lauding the hero's achievement as aimed at reintegrating the hero - who has distinguished himself in

\footnotetext{
${ }^{10}$ Alekseeva draws attention to a formal and stylistic "antiquization" in Petrov's poetry of the early $1770 \mathrm{~s}$ (“Torzhestvennye ody Petrova," 298-300). I suggest that in Petrov's panegyric texts (those tending toward the Pindaric as well as Horatian ends of the spectrum), formal and stylistic antiquization is matched by an antiquization of the envisioned social relationships structuring the cultural field. Thus, the role of the patron in Petrov is perhaps more closely aligned with the Maecenic prototype than with his own contemporary conditions.
} 
battle or athletic competition, thereby isolating himself from his community - into his temporarily abandoned communal environment: the house (oikos), the aristocratic class, or the city-state (polis). ${ }^{11}$ While the Pindaric inheritance is a crucial context for eighteenth-century Russian ode-writers (Lomonosov and Petrov in particular), the relevance of this "integrative function" of Pindar's art for the eighteenth-century Russian panegyric is debatable. ${ }^{12}$ The reintegration model is no doubt premised on very different ideas of citizenship and oratory than those afforded by a centralized autocratic court culture and a public life straining between inscrutability, pageantry, and hesitant steps toward an Enlightenment public sphere. Peter I's self-fashioning and reforms foregrounded colossal heroism and the ideology of meritocracy, i.e., self-distinction and advancement, which came to be paired with deep-seated traditions of clientelism. ${ }^{13}$ Peter's heroic feat, at least so far as prevailing rhetoric was concerned, was conceived largely as delivering his subjects and state from obscurity - a feat of making visible, tantamount to creation rather than integration. The function of the panegyric, though modified somewhat in the milder age of empresses, corresponded to the superhuman trappings of this demiurgic act. The archetypal hero of the Russian ode is held up to the public in much the same way, and the main rhetorical gestures of the ode are to proclaim and marvel at the hero.

There is, moreover, still another incongruity between the triangulated poetpatron-polis relationship in Pindar and its echoes in the poet-patron-empire odes of his Russian eighteenth-century heirs - a crucial difference concerning notions and structures not of heroism and individuality, but community and society. While rhetorically the Russian ode was no doubt a public act intended to broadcast its message widely, in practice the ambit of its reception, especially in the context of the empire as a whole, was delimited. The ode's potential audience was miniscule, and in large part conscious more of such vicissitudes at court a given ode reflected than whatever artistry it evinced. ${ }^{14}$ It was up to the panegyrist, then, to extricate his work from the confining circumstances of its actual circulation, by performatively constructing a broad and unstratified public that might witness both the poet's and the patron's deeds. If Pindar reconstitutes the

\footnotetext{
${ }^{11}$ See Kevin Crotty, Song and Action: The Victory Odes of Pindar (Baltimore: Johns Hopkins University Press, 1982). A more nuanced account of this reintegration is given by Leslie Kurke (The Traffic in Praise: Pindar and the Poetics of Social Economy [Ithaca: Cornell University Press, 1991]), who decodes the conceptions and structures of community and gift exchange embedded in this dynamic.

${ }^{12}$ Kurke (The Traffic in Praise, 79) draws attention to "the constraints of [Pindar's] heterogeneous audience and the essentially integrative function of his art."

${ }^{13}$ For a discussion of this particular blending of meritocracy and clientelism in eighteenth-century Russia, see David L. Ransel, "Character and Style of Patron-Client Relations in Russia," in Klientelsysteme im Europa der Frühen Neuzeit, ed. Antoni Maczak and Elizabeth Mueller-Leuckner (Munich: R. Oldenbourg, 1988), 21130.

${ }^{14}$ The disparate circumstances of the ode's delivery and performance in Classical Greece and eighteenthcentury Russia are no doubt relevant here as well. For all its imaginative appeal, Iurii Tynianov's conception of the eighteenth-century ode as not only a rhetorically performative but also performed genre has since been convincingly corrected in scholarship. Cf. Iu. N. Tynianov, "Oda kak oratorskii zhanr," in Poetika. Istoriia literatury. Kino (Moscow: Nauka, 1977), 227-52; S. I. Panov and A. M. Ranchin, "Torzhestvennaia oda i pokhval'noe slovo Lomonosova: obshchee i osobennoe v poetike," in Lomonosov i russkaia literatura, ed. A. S. Kurilov (Moscow: Nauka, 1987), 175-89.
} 
temporarily disrupted social realm, Russian ode-writers such as Petrov seek to propagate the very discourses not only of individual heroism, but also, equally pressingly, of community and publicity. It is in this light that we might read, as an act both of making public and of making the public, Petrov's repeated presentation of his heroic patrons as engaged in enabling and directing human multitudes. ${ }^{15}$

Consider the explicit interplay of the themes of community, patronage, and the emergence of the poet's voice in Petrov's description of Grigorii Orlov, a frequent recipient of his panegyric verse, in the ode of 25 January 1771:

Сквозь гласы искренних и ревностных желаний, Сквозь тысящи к тебе усердных восклицаний

Возносит ныне свой весела муза тон;

Та муза, что благой ущедрена судьбою,

Представлена тобою

Премудрости пред трон. ${ }^{16}$

[Through the voices of sincere and ardent desires, / Through thousands of zealous acclamations unto you / The merry muse now offers up her sound; / That muse who, lavished by good fortune, / Has been presented by you / Before wisdom's throne.]

In the anaphoric repetition, the muse (muza ... ta muza) - whose invocation spares the poet from directly identifying as Orlov's client - comes to mediate, or enable the slippage, between the story of her emergence from the eager multitude (whose ardent sentiments she shares) and the original circumstance of her distinction from this multitude: Orlov's intercession on the poet's behalf before the empress-wisdom. The rhymes zhelanii/vosklitsanii, ton/tron echo the suggestive but under-articulated linkage, performed by the anaphoric syntax, between the voices of the multitude and patronal intercession, and thus point to the deep-rooted connection between the magnetism of political power and the gift of poetic speech. The entire stanza is animated by an upward aspiration shared by the "thousands," the poet, and even the patron himself, who is in his turn answerable to a still higher authority. The topoi of social cohesion and the poet's rise to distinction are made to coexist: the poet begins as a voice in a crowd, but his art and its recognition by the patron elevate him to a singular position in the course of a short stanza.

The poetic speech that corresponds to this vertical conception of the social realm takes the shape of an acclamation or song, but, in elevating the poet, it also prepares the way for the next stanza's offer of another, more equitable, kind of discursive exchange, a conversation between poet and patron; and another, more authoritative, kind of language addressed to the public, that of moralistic admonishment:

\footnotetext{
${ }^{15}$ On the distinctive role that rhetoric played in eighteenth-century Russia's constructing and regulating forms of secular sociability as opposed to merely responding to those extant in the West, see V. M. Zhivov, Iazyk i kul'tura v Rossii XVIII veka (Moscow: Iazyki russkoi kul'tury, 1996), 63; and Renate Lachmann, Demontazh krasnorechiia (St. Petersburg: Akademicheskii proekt, 2001), 22-44.

${ }^{16}$ Petrov, Sochineniia V. Petrova, 1: 78.
} 
С героем я в сей день беседовать хощу;

Не розы, не луга, не красные дубровы,

Я истины суровы

Днесь свету возвещу. ${ }^{17}$

[Today I wish to converse with the hero; / Neither roses, nor meadows, nor beautiful groves, / But harsh truths / Shall I now proclaim unto the world.]

The bid for conversation with power recalls a striking, if also self-serving, line from Petrov's unpublished epistle to Catherine, first made public in the late nineteenth century by the early Petrov scholar I. A. Shliapkin: "A poet is born into the world to converse with tsars" (Piit roditsia $v$ svet besedovat' $s$ tsariami). ${ }^{18}$ This text, aimed against Petrov's detractors, argues with surprising assurance for the likeness (skhodstvo blizkoe) between rulers and poets: "The tsar must be the master of the people's hearts, / Is not every poet the same, or desirous of being the same?" (Narodnykh dolzhen tsar' vladetel' byt' serdets, / Ne to zhe l'vsiakoi est', il' khochet byt' pevets?). ${ }^{19}$ Thus, the bid for conversation with Catherine presumes a resemblance between the monarch's authority over her subjects and the poet's over his readers (with the latter, markedly expanding his audience to include the entire nation via this analogy).

In the panegyric to Orlov, the possibility of equality between poet and grandee likewise stems from the poet's moral authority over others. And this argument is similarly advanced not with some explanatory subordinate clause (a 'therefore' or 'because'), but through an almost associative shift of a coordinating semicolon, which goes to remind us of the suggestively coordinated anaphora and rhymes of the previous stanza, or the analogical parallels between ruler and poet in the epistle to Catherine. The conversation with the patron (s geroem ... besedovat') and the address to the public (svetu vozveshchu) take place simultaneously, in the proximate future of intention (sei den', dnes') and in the close syntactic vicinity of two independent clauses. We will see further examples of such coordinating syntax and the essentially subordinative relations it paradoxically designates in the next section; suffice it here to acknowledge its role in the parallel conferral upon poet and patron alike of authority over some vaguely defined, enrapt multitude.

The harsh truths delivered to these listeners no doubt rang familiar already to Petrov's contemporaries: rightful and enduring fame comes to a powerful man through good deeds rather than material wealth. In establishing an equivalence between this abstract ideal grandee and Orlov, Petrov was also performing the traditional defense of the panegyric: if the patron is shown to be truly meritorious and not self-interested, the poet, too, offers well-earned praise, unmotivated by hopes of material gain. While this line of argumentation should hardly come as a surprise, its rhetorical outfitting in Petrov deserves attention. Once again the panegyrist devises tight syntactic structures to assert

\footnotetext{
${ }^{17}$ Ibid., 1: 79 .

${ }^{18}$ Shliapkin, "Vasilii Petrovich Petrov, 'karmannyi' stikhotvorets Ekateriny II,” 386.

${ }^{19}$ Ibid.
} 
the interdependence between ruler/grandee and his subjects. The ideal patron's pursuits are not solitary or self-serving, but instead directed entirely toward others: "So as not to be alone, he creates many" (Chtob byt' ne odnomu, on mnogikh sozidaet) and "since he enlivens all, he lives" (on zhiv, kol'vsekh zhivit ${ }^{20}$ ) - a life-creation that recalls the Petrine myth of modern Russia's origins. Similarly, Orlov is "alive in countless beings, not in one" (Vo sushchestvakh neschetnykh, ne vo edinom zhiv ${ }^{21}$ ), and is possessed of fortune "for everyone in society, not for himself" (Dlia vsekh vo obshchestve, ne dlia sebia schastliv ${ }^{22}$ ). Patronage is here legitimized through an evolving discourse of social utility. Conversely, it is through the benefactor's support that the social realm comes into view, if not into existence itself. The close connection of patron and community is once again demonstrated through the recurring adjacency of the words denoting them: alone/many (odnomu/mnogikh), countless/one (neschetnykh/edinom), everyone/himself (vsekh/sebia). But this is not a community receiving the hero into its fold, as Pindar's public is theorized. Petrov's public, by contrast, remains merely the beneficiary of the patron's liberality, which is, moreover, presented as dispensing not only fortune (schastliv), but life (zhivit) itself.

One source for this model of top-down enablement can undoubtedly be located in patriarchy, or, more broadly if we are to include Petrov's odes to Catherine, progeneration. Indeed, seeing Orlov as a father to his constituencies is the most obvious explanation for the repeated references to his giving them life. The connection between patronage and paternity, already implicit in the terms' etymological affinity, is even plainer in another of Petrov's panegyrics, this one addressed to P. A. Rumiantsev (1775), in which the hero is likened to a father of the army:

И, как отец среди обильна домочадства, Всех равно любит, всех объемлет, как детей, И кажет тысячи к блаженству им путей. ${ }^{23}$

[And, like a father amid a plentiful household, / He loves everyone equally, embraces everyone as children, / And shows them myriad paths toward bliss.]

In this victory ode, Rumiantsev's subordinates in the military are presented as members of his extended household; the patron's relation to his clients easily fits the patriarchal model of governance and social organization attending an entire range of communal associations in early modern Russia, from the family to the state. ${ }^{24}$

In the patriarchal model, the hero's body is generative and fruitful, requiring no recompense for its procreative giving ("freely-giving creator of happiness and joy"; bezmezdnyi schastiia i radostei tvorets). Such reciprocity as is expected is not a matter of

\footnotetext{
${ }^{20}$ Petrov, Sochineniia V. Petrova, 1: 80.

${ }^{21}$ Ibid., 1: 82.

${ }^{22}$ Ibid.

${ }^{23}$ Ibid., 1: 122.

${ }^{24}$ Another ode, glorifying Rumiantsev's campaign against Ottoman forces, has the patron as "leading children in the paths of glory" (Rumiantsev, koi detei vedia pokhval sledami). Ibid., 3: 217.
} 
sacrifice (zhertv ne ozhidaet), but of affect. Thus, in an ode commemorating the awarding to Catherine of the title of the Great, "mother of the fatherland" (a tour de force of progeneration), the speaker employs an anadiplotic repetition to mirror the symbiosis it describes, and link the empress-mother's modest desire for her subjects' love with these subjects' fulfillment of their duty to love her: "Your wish is, by us, to be loved; / To love You as a mother is our inviolable duty" (Zhelanie Tvoe est' byt' ot nas liubimoi; / Liubit' Tebia kak mat' nash dolg nepristupimyi). ${ }^{25}$ The collective created through the act of patronage is thus held together by a familial structure in which the patron's parental generosity seeks no reward; and the subjects' admiration, magnified in the poet's lyric offering, is understood as filial piety.

Parallel to the familial order, another source for conceptualizing the patroncommunity relationship in Petrov involves some notion of the body politic, in which the patron comes to embody the aspirations and gratitude of his beneficiaries. But instead of the contractual patron-client relationship usually associated with the body-politic concept, this model establishes a kind of specular affinity: the patron, especially one in military command, is possessed of an all-encompassing vision, and the subjects are animated by a scopic desire for witnessing and envisioning the powerful man and his virtue. Thus, a military campaign becomes a mere pretext for displaying Rumiantsev's goodwill: "It seems to me the strife arose so that the whole world might witness / How great, Rumiantsev, is your beneficence" (Ia mniu, vozdviglas' bran', chtob ves' byl mir svidetel', / Kolika est' tvoia, Rumiantsov, dobrodetel'). ${ }^{26}$ The patron's acts are only a means to externalize his virtue, for his subjects to behold him.

The model of autocratic charisma that foregrounds the monarch's - and, on a smaller scale, the patron's - scopic presence in his subjects' imaginations has been theorized by Louis Marin in Portrait of the King; the subjects understand themselves as such, as capable of the contemplation of power, only when beheld by the monarch: the king "can be seen only to the extent that he looks at us, since one contemplates only when taken and seized in the limits of his scopic beam." ${ }^{27}$ Inasmuch as the logic of the king's magnetism is replicated on a smaller scale in the patron's charisma, this scenario of power sees the patron focalize the desires of his beneficiaries, not merely on the superficial level of granting them favors, but more deeply, where these desires are first conceived. This is another sense in which the patron gives life to the multitudes who depend on him. Petrov describes the ideal grandee in the ode to Orlov as "a beam of very many hearts" (mnozhaishikh luch serdets ${ }^{28}$ ), and such a beam or ray conveys the specular nature of the patronal dynamic. ${ }^{29}$ Paradoxically, it is in the lyric, with its recurrent

\footnotetext{
${ }^{25}$ Ibid., 3: 16.

${ }^{26}$ Ibid., 3: 169.

${ }^{27}$ Louis Marin, Portrait of the King (Minneapolis: University of Minnesota Press, 1988), 72.

${ }^{28}$ Petrov, Sochineniia V. Petrova, 1: 80.

${ }^{29}$ Petrov similarly employs a beam or ray to establish the specular connection between patron and poet in his 1775 ode on Russia's armistice with the Ottoman Porte: "This is Catherine's ray! // O beloved ray! Ray resplendent! / The organ of my senses does not lie; / How pleasant, warm, and clear you are! / How alive I am, through you!" (Sie Ekateriny luch! // O luch vozliublen! Luch prekrasen! / Moi chuvstviia organ nelzhiv; / Kol' ty priiaten, tepl, i iasen! / Koliko ia toboiu zhiv!). Petrov, Sochinenia V. Petrova, 1: 90.
} 
gesturing towards oral performance, that the trajectory of this scopic beam comes to be traced most compellingly.

Petrov is hardly an original philosophical mind; but as the examples I cite demonstrate, he consistently succeeds in finding a sophisticated rhetoric for the political mystery that underwrites patronage as both a sociopolitical framework and a lyric event. Witness his remarkable - albeit also borderline comical - depiction of Rumiantsev as omnipresent spirit, hovering over the battlefield and inhabiting the very souls of Russian soldiers:

Он малу рать свою во милион умножил;

Но милион врагов сжал, стиснул, уничтожил.

Известен лишь ему прием употребя,

На многи разделил Румянцовы себя,

И в духе Россами внутрь чуемом, незримом,

Повсюду носится горящим Серафимом.

О как разширился по вражьей всей земле. ${ }^{30}$

[He multiplied his small army into a million; / But a million enemies he grasped, squeezed, destroyed. / Using a method known to him alone, / He split himself into many Rumiantsevs, / And as a spirit, unseen, yet internally felt by the Russians, / He rushes about everywhere as a burning Seraph. / O, how he expanded round the whole enemy territory.]

Through "a method known to him alone," the general becomes his army, as the poem activates another meaning of the enlivenment that we have seen Orlov perform for his beneficiaries in the ode of 1771: the act of inspiriting unseen but felt by all, with all its attendant scriptural echoes. In imagining Rumiantsev as miraculously self-dividing, the passage interrogates the ability of one man ostensibly to exceed the physical confines of a single body, to surpass the agency of a single man - an excess that serves as the very premise of both centralized power and the donative endeavors of patronage.

This is of course the paradox inherent in the many's voluntary investiture of their will in an individual, a phenomenon theorized in a whole tradition from Thomas Hobbes to Carl Schmitt, and mystifying enough that the latter can categorize it as "political theology." Indeed the theological dimension of panegyric address - or, some would go as far as to say, the devotional element in most lyric utterances - cannot be overstated. But the panegyric also poses itself the task of a different kind of theoretical intervention, that of rendering power a poetic event describable by an all-seeing speakerly presence; and the task of conceptualizing the inspiritment of the multitudes that Rumiantsev here performs as analogous to or even the same as inspiration.

Thus could we read Petrov's famously lengthy epic descriptions of battles, sometimes running on for dozens of pages, as performing simultaneously the patron's ubiquity (his miraculously diffused spirit animating every sword-thrust, every step of the

${ }^{30}$ Ibid., 3: 193-94. 
victorious Russian boot), and the concomitant expanded perspective of the inspired poet, who sees and narrates it all. ${ }^{31}$ And thus do we arrive at another, for our purposes most crucial, model for thinking of patronage as Petrov's central theme. Through a suggestive rhetorical reactivation of the 'spirit' in 'inspiration' (dukh in vdokhnovenie and, in more sacral terms, odukhotvorenie), Petrov presents the economies of sponsorship and encouragement - which such lyricists of patronage as Pindar and Horace often rendered less abashedly in terms of gift exchange - as the essential poetic experience of inspiration. What Rumiantsev grants to Petrov within his verse is a spiritual and poetic rather than material endowment: "From your spirit it [the poet's voice] borrows its spirit, / It has no need for the god of poetry" (Ot dukha tvoego on [golos poeta] svoi zaemlet dukh, / Net nuzhdy dlia nego vo stikhotvorstva boge). ${ }^{32}$

Patronage as a mode of poetic inspiration will be the focus of the next section of this article. Here I would sum up my discussion of the patron's role in enabling the multitudes with an illustrative passage from another address to Orlov (1772), which considers in tandem the patron's beneficence vis-à-vis the public and the poet:

Не очевидный ли здесь всяк тому свидетель, Сколь может одного из смертных добродетель!

Пришел, узрел, воздвиг несчетны вдруг семьи;

Жизнь вдунул и в меня; там искренни мои. ${ }^{33}$

[Is not everyone here an eyewitness / To how much one mortal's virtue can [achieve]! / He came, he saw, he raised up countless families at once; / Into me, too, did he breathe life [zhizn'vdunul; or: Me, too, he inspirited with life]; there lie my sincerities.]

The vocabulary of praise in this passage is now clear: witnessing and virtue (svidetel' and dobrodetel') exist in a complementary rhyming relationship; the one (odnogo) is shown to have enabled the countless many (neschetnykh); the patron's charity exceeds mere gift exchange, breathing life itself (zhizn' $v d u n u l$ ) into its beneficiaries; the almost de rigueur defense of panegyric sincerity is supported by the ascertainment of the patron's colossal virtues and the poet's debt of life. Substituting the imagery of progeneration (vozdvig ... sem'i) for the third, aggressive, term in the "veni, vidi, vici" dictum ("he came, he saw, he raised up"; prishel, uzrel, vozdvig), the poet reconciles the two contradictory sides of the patron's achievement: the destructive conquest of a military hero and the generative charity of a benefactor. Finally, the poet conceives of himself not only as witness to the hero's deeds, like the rest of the admiring multitude, but the receiving vessel for his lifeinfusion. In the grammar of patronage, he is the sentence's object, but one that acquires a voice precisely through the patron's gift.

\footnotetext{
${ }^{31}$ These remarks are intended in part as a response to Nadezhda Alekseeva's call ("Torzhestvennye ody Petrova," 304) to attend to the increasing volume and intensification of epic tendencies in Petrov's later lyric.

${ }^{32}$ Petrov, Sochineniia V. Petrova, 3: 168.

${ }^{33}$ Ibid., 3: 96-97.
} 
Because of its foundational status for any lyric utterance, inspiration is as much a concern for the pre-Romantic lyric as it is for the Romantics (even if its placement at the center of aesthetic discourse is most associated with the latter). That secularized religious enthusiasm, which the Romantics imagine engulfing the chosen individual mostly in situations of social isolation, Classicist panegyric discovers, by contrast, in the contexts of social encounter, as a sentiment seizing the collective, for which the poet is the most eloquent spokesman. Petrov's rhetorical logic, which operates largely through various structures of analogy and repetition, establishes parallels between the enthusiasms of the crowd and the muse, on the one hand, and on the other, between the creative molding, moral admonishment, and spiritual possession that the patron and poet both exercise upon the multitudes. ${ }^{34}$ If we do not brush aside the panegyric's claims to and about inspiration as ipso facto tainted by participation in patronal relations; if, that is, inspiration is extricated from the ethical orthodoxies surrounding aesthetics, then a literary-historical narrative that attempts to dismiss all forms of poetic address to the patron as irrelevant - as merely a stage to be "outgrown" in the development of poetic autonomy and the concomitant consecration and professionalization of literature appears less than satisfying.

\section{Te me esse alterum ${ }^{35}$}

To what extent can we speak of lyric subjectivity in the context of patronage, wherein the poet's autonomy appears compromised by his unceasing engagement with an other, upon whom, moreover, he depends? And if it would be anachronistic to apply subjectivity as a concern to the early modern lyric, or more specifically to the eighteenthcentury Russian panegyric, what other frameworks for analyzing the integrity of the lyric voice in occasional verse can we appeal to?

The rift created by the purported conflict between the pragmatic and aesthetic readings of the ode - a rift this essay seeks to traverse - relegates the scholar attempting to reclaim these texts for what they say about poetry to the position of one naively blinded by the rhetorical conventions masking the actual circumstances of favorexchange that the panegyric often responds to or intends to catalyze. Thus, arguments that do not foreground patronage as a professional predicament, but rehabilitate it as poetic subject matter like any other, lend themselves to predictable criticisms of the sort leveled at practitioners of close reading or New Criticism generally, namely, that they

\footnotetext{
${ }^{34}$ Recall, as identified above in the 1771 ode to Orlov, the distinct yet paired modes of praising the patron and conversing with him.

35 This famous phrase from Cicero's correspondence with Julius Caesar - "you are a second self to me" couches the dialogue between philosopher and ruler, one traditionally steeped in the patron-client exchange, in the language of selfhood and partnership. Cicero: Select Letters with English Introductions, Notes, and Appendices, ed. Albert Watson (Oxford: Oxford at the Clarendon Press, 1881), 188.
} 
serve to champion, however unintentionally, the very forms of disguise - of social context behind impassioned poetic speech - that patronage as an ideology motivates. ${ }^{36}$

One solution for bridging this interpretive divide has come from within the sociohistorical analytic framework and calls for refining our view of patronage as an institution by contrasting clientelism (writing to order or for pay, which is truly restrictive of creativity) and what in French is denoted by the term mécénat (the Russian metsenatstvo) and implies no artistic unfreedoms or specific obligations other than those imposed by gratitude. ${ }^{37}$ Reading the Russian panegyric as underwritten by the looser dependency of metsenatstvo rescues the poet somewhat from the charge of mere toadyism, making it possible to grant him a measure of (however attenuated) creative autonomy. ${ }^{38}$

Another productive approach to reconciling the tendencies to read occasional verse either solely for its occasion (i.e., sociohistorically) or for its language has been to recognize in this conflict a space of tension between these two tendencies already thematized in the poetry itself. Thus, one scholar of Horace ponders whether we might not reconceive the rhetorical framing of patronage in Horace's poetry to Maecenas as resisting rather than masking the economy of subjection in which the poet participates: "If the gifts of patronage symbolically expropriate the poet's self, obligating him to make the return gift of poetry as the embodied or 'reified' form of his labor, then in what ways and to what degree does the figurative language concerned with this exchange permit resistance to that same patronal discourse?"39

A third approach, and one that I would offer as most germane to the analysis of Petrov's occasional verse, would be to see the panegyric as articulating a different view of lyric subjectivity, one focused not on the poet's autonomy and detachment from the social realm or on resisting poetry's commodification, but rather on the communicative circuit that a lyric utterance activates, on the making of the poet's voice in the very act of indenturing it to another.

\footnotetext{
${ }^{36}$ This critique has been made, for instance, against Barbara Gold's rejection of toadyism as a framework for thinking of patronage in antiquity in Literary Patronage in Greece and Rome (Chapel Hill, NC: University of North Carolina Press, 1987).

${ }^{37}$ This influential argument was developed for French Classicism by Alain Viala (Naissance de l'écrivain: sociologie de la littérature à l'âge classique [Paris: Les éditions de Minuit, 1985], 51-84), and recently has been productively applied in the context of the Russian eighteenth century, specifically to Alexander Sumarokov, by Marcus Levitt (Early Modern Russian Letters: Texts and Contexts [Boston: Academic Studies Press, 2009], 206).

${ }^{38}$ Scholars of the Russian ode have identified several other of its methods for claiming poetic autonomy, particularly to account for what one has called "the daring of Derzhavin." See Anna Lisa Crone, The Daring of Derzhavin: The Moral and Aesthetic Independence of the Poet in Russia (Bloomington, IN: Slavica, 2001). As V. A. Zapadov shows ("Problema literaturnogo servilizma i diletantizma i poeticheskaia pozitsiia G. R. Derzhavina," XVIII vek, vyp. 16 [1989], 56-75), noble writers' self-professions as dilettantes were to defend against the potential charge of mercenarism or servility (servilizm); Joachim Klein ("Poet-samokhval: 'Pamiatnik' Derzhavina i status poeta v Rossii XVIII veka," Novoe literaturnoe obozrenie 65 [2004]: 148-69) analyzes the extent to which aspirations to autonomy corresponded to, and performatively enhanced, the poet's status in this period.

${ }^{39}$ Phebe Lowell Bowditch, Horace and the Gift Economy of Patronage (Berkeley: University of California Press, 2001), 3-4.
} 
In the previous section, we have seen Petrov define the odic hero through his acts of benefaction, recasting epic heroism from a phenomenon of action to one of relation (recall "since he enlivens all, he lives"; on zhiv, kol'vsekh zhivit from the 1771 ode to Orlov). This is a heroism characteristic of the panegyric, inasmuch as this mode proceeds chiefly via dialogic invocation, rather than narration or description. The public is similarly defined through its relation or proximity to the patron, whether as recipient or admirer of his goodwill, figured as nothing less than the gift of spirit or life. The odic social realm in general is vast and hierarchy-bound, but Petrov's rhetoric of relationship shapes it also as tightly interconnected. The dense syntax, decried already by Petrov's contemporaries as artificial, and remarked upon by many a historian of eighteenth-century Russian literature, in fact conveys the closeness of these bonds.

Examples are easily multiplied. Thus, in the 1775 ode to Rumiantsev, the poet discerns a chain of benefaction connecting Rumiantsev to Catherine, and Catherine to the divine realm: "I know Catherine sends him here; / She is the benefactress for him, and for Her [the benefactress] is fate" (Ia znaiu, shlet ego siuda Ekaterina; / Ona emu, a Ei spospeshnitsa sud'bina). ${ }^{40} \mathrm{~A}$ similar chain of blessings extends to Catherine's subjects in the 1778 ode on her coronation day: "Unto her flows myrrh from on high, / Unto you a rain of blessings" (Na niu lietsia miro svyshe, / Na vas blagoslovenii dozhd'),$^{41}$ echoed by an even shorter line in another 1778 ode, on Catherine's nameday: "You are the Heavens' greatest gift unto mortals" (Ty smertnym luchshii dar Nebes). ${ }^{42}$ To these examples of a one-way hierarchical linearity in Petrov can be added others that foreground the flow of reciprocal exchange. The dictum that "[w]hosoever builds happiness for mortals / Is, o Lyre, worthy to be sung" (Kto schast'e smertnykh stroit, / Togo, o Lira, pet' dostoit) ${ }^{43}$ from the 1775 address to Potemkin is structurally replicated in the 1778 coronation-day ode, where we see Catherine the benefactress as grammatical subject, and the reciprocal praise of her admirers as predicate: "The benefactress of the universe / Deserves to be sung by all” (Blagotvoritel'nitsa sveta / Dostoina byt' vsemirno peta). ${ }^{44}$ In Petrov's epistle to Catherine accompanying his completed translation of the Aeneid (1786), the poet recasts what in earlier examples had been a matter of predication as a baroque polyptoton: "And simply from those who are Yours do we render what is Yours unto You" (I prosto ot Tvoikh Tvoia Tebe prinosim). ${ }^{45}$

The parataxis in the first few examples paradoxically figures the subordinating dynamic that the sentences narrate as a matter of syntactic coordination. Similarly, the repeated, almost incantatory, capitalized pronouns just cited - which denote, as if through an illusion of identity, Catherine's subjects, their tributes to her, and the Empress as addressee - disguise the fundamentally hierarchical nature of the proceedings (everything, after all, belongs to the empress; hence these somehow particularly possessive pronouns) within an equalizing dynamic of exchange (conversation and

\footnotetext{
${ }^{40}$ Petrov, Sochineniia V. Petrova, 1: 128.

${ }^{41}$ Ibid., $1: 142$.

${ }^{42}$ Ibid., 1: 169 .

${ }^{43}$ Ibid., 1: 111 .

${ }^{44}$ Ibid., 1: 139 .

${ }^{45}$ Ibid., 3: 277.
} 
parataxis in our other examples). If patronage as an institution rests on an obviously stratified social order, patronage as a discourse, by contrast, foregrounds the social leveling effected by the bonds of friendship and mutual obligation. In his panegyric rhetoric, honed throughout an extensive corpus of odes and epistles, Petrov attends to both the vertical and horizontal planes of the social order by letting his syntax, as a coordinating and subordinating instrument of grammar, embody the coordinating and subordinating instrument of power that is patronage.

Here I would further posit the poet-patron interdependence as constitutive not only of the social realm, but also, via the discourse of friendship, of the lyric voice itself. But before we turn to that latter poetic issue, a disclaimer about friendship as a sociopolitical construct is in order. Like the ethics of patronage, the friendship discourse of early modernity is easily misread at our temporal remove. The post-Sentimentalist lens, in particular, grants friendship a far narrower expressive range than in Petrov's time; and a narrower social ambit, limited to interpersonal and intimate bonds rather than, for instance, broadly political ones; intimate friendships are, moreover, often conceived by moderns as offering a haven from the public realm. Considering Petrov's serious intellectual involvement with Classical antiquity, it is worth briefly attending to those earlier manifestations of friendship that were in fact about to be displaced by Sentimentalist discourse even as Petrov was writing. ${ }^{46}$

While Pindar and Horace were no doubt most central to Petrov's articulation of friendship in his verse, others might also be adduced. Thus, if for Petrov's younger contemporary, the Sentimentalist Nikolai Karamzin, the affect most associated with friendship is characterized by emotional outpourings and professions of sincerity among close associates, in the premodern and early modern world, friendship and flattery appear discursively interconnected, or so similar that attempting to disentangle them raises troubling concerns as to language's very intelligibility. Plutarch, for instance, in his treatise on "How to Tell a Flatterer from a Friend," discusses the inability (nurtured by the blinding excesses of self-love) to distinguish whether praise is motivated by true friendship or flattery; and considers this conundrum an important political concern. ${ }^{47}$ Along the same lines, a word used in ancient Rome to denote a practice falling under our present-day, rather loosely defined, rubric of patronage, was amicitia; this term applied to a considerable array of purportedly equal relationships, ranging from those between individuals to those between states. ${ }^{48}$ Though not altogether unimportant, the pursuit of

\footnotetext{
${ }^{46}$ Here I offer only a few particularly vivid examples of how the discourse of friendship was intricately inscribed into the history of political thought and discourses of public virtue. For a broad-ranging survey of the history of the term "friendship" (druzhba) and conception thereof in premodern and early Russia, including the Russian reception of Greco-Roman thought on unequal friendships, see Dmitrii Kalugin, "Istoriia poniatiia 'druzhba' - ot Drevnei Rusi do XVIII veka," in Druzhba: Ocherki po teorii praktik, ed. Oleg Kharkhordin (St. Petersburg: Izdatel'stvo Evropeiskogo Universiteta v Sankt-Peterburge, 2009), 187-289.

${ }^{47}$ Plutarch, Moralia (Cambridge, MA: Harvard University Press, 2005), 1: 261-396.

${ }^{48}$ On amicitia, and particularly the interplay between patrocinium-clientela and amicitia, see Koenraad Verboven, "Friendship among the Romans," in The Oxford Handbook of Social Relations in the Roman World, ed. Michael Peachin (Oxford: Oxford University Press, 2011), 404-21. Needless to say, Petrov would not have been aware of all the relational intricacies now being uncovered by cultural historians; but these
} 
sincerity in these relationships takes a back seat to far more pragmatic concerns over benevolence, virtue, and political and personal alliances. Finally, we should also historicize the ethical system encompassing early modern friendship, particularly of the kind read by neo-Classicists from the patronage-bound Classical poetic tradition. Premised upon only a tenuous demarcation between the private and public domains, or rather, viewing both domains as animated by the same issues, Aristotelian ethics concerns itself with questions of good living and individual virtue alongside and tantamount to equitable political organization, and examines friendship as a political good closely linked with matters of community and justice, and incompatible with tyranny. ${ }^{49}$ The capacity of individuals in a society - particularly those unequal in their rank, power, or age - to form friendships and advance their well-being through these ties attests, according to Aristotle, to the overall health of the political order and the absence of despotism.

If Petrov's appeals to friendship denote a set of relationships that acknowledge, in a hierarchical society, public associations based on commonality; and if we read the grandee's or monarch's willingness to permit the consideration of such commonalities as a political virtue, then the porousness of the generic boundary between odes and epistles, between what is addressable to the empress as opposed to her courtiers or other mortals, emerges in Petrov's panegyric corpus as far more than the poet's stylistic experimentation with the dissolving genre hierarchy. It can also, then, be read as a bid to poetically realize a political order - one that recognizes, from within a (non-tyrannical) autocracy, the ethical standard of universal humanity.

We see this dynamic in the following analogy, performed via Petrov's characteristic parataxis, from the epistle to Catherine accompanying his translation of the Aeneid: "To amaze the universe is a gift given to You from on high: / To strongly feel Your deeds is my talent" (Vselennu izumliat' Tebe dar svyshe dan: / Moi, krepko chuvstvovat' dela Tvoi, talan).$^{50}$ Even as the poet's agency is limited to reacting to the monarch's, and the governing sentiment for the poet is that of dutiful subjection, the syntactic parallelism points toward an alternative conception of the social order, analogizing empress and poet

concepts and practices do form the backdrop of Horace's writings to his patrons, and would have reached Petrov inflected by these poetic treatments.

${ }^{49}$ See especially book VIII (94-108) of Aristotle, Nicomachean Ethics (South Bend: Infomotions, Inc., 2001). Already in the seventeenth century, Aristotle's writings were taught at the Moscow Greek-Latin-Slavonic Academy from which Petrov would graduate; and quotations from Aristotle were frequently anthologized in Russian translations along with Cicero and the Stoics. (I am grateful to Dmitrii Kalugin for clarifying the limited range of circulation and authority of Aristotelian ethics, as well as the emphasis placed on its moral rather than political applications, in eighteenth-century Russia.) But we might also speculate that Petrov received and interpreted Aristotelian conceptions of social relations through another channel, namely, the political-ethical deliberations in John Milton's Paradise Lost, which Petrov translated into Russian in the 1770s. For an illuminating treatment of the questions of tyranny, friendship, and Aristotelian ethics in Milton, see Gregory Chaplin, "Milton against Servitude: Classical Friendship, Tyranny, and the Law of Nature," in Discourses and Representations of Friendship in Early Modern Europe, 1500-170o, ed. Daniel T. Lochman, Maritere López, and Lorna Hutson (Burlington, VT: Ashgate, 2011), 209-23.

${ }^{50}$ Petrov, Sochineniia V. Petrova, 3: 276. 
in their corresponding giftedness (dar; talan).$^{51}$ The empress's deeds are in fact interposed between the possessive pronoun (moi) and the gift (talan) that reference the poet, imagining, on the graphic level, poetry's ability not only to react to, but also absorb the monarch's actions. And while this passage hardly presumes the possibility of friendship between poet and monarch, the presumption of commonality or analogy is an argument for both poetic agency (not to be conflated with autonomy) and the enlightened liberality of Catherine's regime.

Might we not interpret, more generally, the continual reshuffling of the terms "benefaction," "virtue," "public good," and "ideal ruler" in close proximity to protestations of friendship in Petrov's panegyric corpus as not only attempting to defend his verse against accusations of insincerity and obsequiousness, but also as a bid to apply the vocabulary, even if only as topoi, of Classical ethics and politics to the regime of royal and noble favors that Petrov sought to praise? Indeed, reading Petrov's patronage verse as existing in this, among other modalities - that is, as retrospectively engaging the multiple discourses of patronal relations and friendship acquired through his studies; as responding to the topical demands of Catherine's political order and her courtiers; and as recognizing the new social frameworks arising with the Age of Sensibility - affords a deservedly nuanced reading of the striking passages on friendship between courtier and poet found in his oeuvre.

Perhaps the most remarkable declarations of friendship in Russian preSentimentalist panegyric appear in two late Petrov texts: the 1791 lament on the death of Potemkin (the ninth and final poem Petrov dedicates to him), and the 1796 ode to admiral N. S. Mordvinov. ${ }^{52}$ Much like Petrov's other panegyric texts, both poems articulate the poet's connection to his hero through the topos of glory and its poetic transmission, which emphasizes the complementarity of the hero's deed and the poet's word. Yet even within this topos, Petrov claims an unusual level of empowerment - not, to be sure, in the sense of creative autonomy, but on the contrary, a privilege deriving from the poet's frequently thematized connectedness to his patron.

In his address to Mordvinov, Petrov, beleaguered by critics (imagined and quite real) of his enthusiasms, presents an entire series of ever-intensifying claims to the pair's untroubled and mutually acknowledged affinity, as illustrated, indeed, in nearly every line in this ode:

Что я вещаю, то поемлешь ты, Мордвинов!

То голос мой, а мысль твоя.

\footnotetext{
${ }^{51}$ Recall the passage quoted earlier from another epistle to Catherine, where Petrov argues for a "close resemblance" (skhodstvo blizkoe) between monarchs and poets.

${ }^{52}$ The fact that these vivid examples of friendship discourse are culled from this later period in Petrov's career no doubt attests to his receptiveness to now-dominant Sentimentalism, but the topoi he uses are not new; nor is the construction of a close emotional interdependence between poet and patron (whether stylistically or via argumentation) unimaginable in his earlier verse.
} 
Кто вступит в спор со мною,

Как солнцем, я тобою

Снищу победы честь. ${ }^{53}$

[That which I proclaim, you possess, Mordvinov! / It is my voice, but your thought. / ... / Whosoever shall cross swords with me, / As with the sun, with you I / Shall gain the honor of victory.]

Так в добродетели души твоей прекрасной

Есть часть, почтенный друг! и мне?

И мне не заперт ты, как образ тверди ясной

И неги, сродныя весне.

Не обща в море служба,

Но дар небесный, дружба,

Творит, что есть твое,

Как собственно мое.

Мое наследие - молва приятна о́на,

Котора о тебе, теча,

Распространяется и паче лирна звона

Пленяет сердце мне, звуча.

Мое наследье - всяки

Твоя отлика, знаки:

Красой твоих рамен

Красуюсь я надмен.

Твоя, о друг! еще во цвете раннем младость,

Обильный обещая плод,

Лила во мысли мне живу, предвестну радость:

Ты будешь отчества оплот.

Свершение надежды

Моими зря днесь вежды

И славу сбытая,

Не возыграю ль я ${ }^{54}$ [Emphasis mine.]

[So in the virtue of your beautiful soul / Is there also a part - honorable friend! - for me? / And to me you are unlocked, like an image of the clear firmament / And of comfort akin to spring. / Not our common service at sea, / But the heavenly gift, friendship, / Makes what is yours / Mine proper. // My legacy is this pleasant talk / Of you, that in flowing / Spreads and, stronger than the lyre's chime, / Captures my heart with its sounds. / My legacy is any / Sign of your distinction: / With the splendor of your shoulders / I too stand in splendor, proud. // Your - o friend! - youth, still in its early bloom / Promising ample

\footnotetext{
${ }^{53}$ Petrov, Sochineniia V. Petrova, 2: 183-84.

${ }^{54}$ Ibid., 2: 192-94.
} 
fruit, / Poured living, prophetic joy into my thoughts: / You would be a bulwark of the fatherland. / The fulfillment of this hope // Witnessing today with my own eyes / And glory come to pass, / Will I not sing?]

If the I/thou relationship can be said to underlie all lyric utterances as expressing the speaker specifically for some addressee, one would be hard pressed to find a more glaring externalization of this phenomenon than Petrov's address to Mordvinov. Here it is directly through the personal and possessive pronouns that the poet's and patron's aspirations, accomplishments, and legacies are insistently and creatively interlaced. Inasmuch as they designate the myriad ways the two "friends" recognize and enable each other, and the way the poet takes possession of the hero's assets (Tvorit, chto est' tvoe / Kak sobstvenno moe) in order to begin to speak, the pronouns channel the odic enthusiasms of praise and admiration for the hero with which the poem commences into a language of reciprocity and companionship, and ultimately an abstract celebration of friendship - the sentimental topos with which the poem concludes.

The initial narrative of heroic distinction (otliki) gives way to what is arguably the poem's central narrative, that of the poet's recognition and enablement by the honored friend-patron (pochtennyi drug - a masterful collocation of hierarchy and equality), and a final affirmation of commonality and universal truths:

Коль истинно когда друг друга смертны любят,

Душами сладкий не́ктар пьют,

И существо свое чрез дружество сугубят,

Из сердца в сердце чувства льют.

Расширь мне, Феб, дух тесный,

Прославить дар небесный;

Направь мою гортань

Воздати дружбе дань.

Так! дружба дар небес, мне тако Феб вещает,

Та грудь с биеньем жил мертва,

Которая в себе сих искр не ощущает:

Жизнь смертных дружбою жива.

Твой друг глас сердца внимет,

С природной лаской примет

Твоих сложенье строк

За дружества венок. ${ }^{55}$

[When mortals love each other truly, / They drink sweet nectar with their souls, / And deepen their essence through friendship, / From heart to heart they pour their feelings. / Expand, Phoebus, my constricted spirit, / To praise the heavenly gift, / Guide my throat / To give friendship its due. // It is so! friendship is a heavenly gift, Phoebus tells me, / That

${ }^{55}$ Ibid., 2: 196-97. 
breast with its pulsing of the veins is dead, / Which does not feel these sparks within: / The life of mortals is alive through friendship. / Your friend will hearken the heart's voice, / With a natural gentleness shall accept / Your versifying / For a wreath of friendship].

This extended coda in fact amounts to an elaboration of the same circuits of receptivity that Petrov constructs through condensed aphorisms on numerous occasions, as we have seen, throughout his oeuvre. Here two mortals deepen their essence (sushchestvo) through their recognition of each other in heart-to-heart outpourings; Apollo (Feb) is entreated to expand the poet's spirit (rasshir' ... dukh tesnyi) in order to enable poetry, figured also as a tribute to friendship (druzhbe dan'); and the ultimate goal of poetic expression turns out to be its acceptance by another (tvoi drug ... vnimet ... primet). The association between poet and patron - represented here, in a universalizing language, as two mortals - is, moreover, depicted, as in our earlier examples, as an instrument of lifegiving and inspiritment (zhizn'smertnykh druzhboiu zhiva).

Poetic agency for Petrov does not originate in autonomy. Poetry exists, rather, to cultivate and broadcast its dependency upon a more powerful other, both as source and recipient of inspiration. This interdependence is conveyed with the greatest intensity in a text commemorating the loss of the patron, the lament over Potemkin's passing. In striving to recover enlivening contact with an interlocutor gone forever, the lyric reaches an almost libidinal fervor ${ }^{56}$ :

Еще в очах моих твой зрак пресветлый зрится, Еще сладчайший глас в ушах моих твердится.

.............................

Креплюся, но когда на твой я гроб взираю,

Сам, кажется, с тобой до срока умираю.

Остановляется и мысль моя и кровь;

Всё мертво, лишь жива одна к тебе любовь.

Судьба, казалось, с тем в живых меня блюла, Чтоб было петь кому твои, герой, дела.

Какому должно быть той жребию души, Что, с лучшею себя расставшись половиной, Живет и движется печалию единой?

И муза им моя, и муза им состонет, И вся в слезах, твой труп препровождая, тонет;

Кто будет ей, увы! защита и покров, И ободрение, хоть слабых, в ней даров? Кто голосу ее с таким усердьем внимет?

${ }^{56}$ Bowditch (Horace and the Gift Economy of Patronage, 17) notes among "the most distinctive features of the discourse of benefaction ... the libidinal or emotive language in which the practice of gift giving was conducted." 
Так дружбой озарит и так ее объимет?

Ко персям так прижмет? о, горе! о, напасть!

$\mathrm{O}$, нестерпимая невинну сердцу часть! ${ }^{57}$

[In my eyes your brilliant gaze is still seen, / In my ears your sweet voice is still affirmed. / ... / I brace myself, but when I look upon your grave, / I myself, it seems, die with you before my time. / My thought and my blood stop; / All is dead but my love for you. / ... / Fate, it transpired, kept me among the living / Only so that there would be someone to sing your deeds, hero. /... / What should be the lot of the soul / That, having parted with its better half, / Dwells and moves in sorrow alone? / ... / And my muse, my muse cries together with them / And, accompanying your body, drowns in her tears; / Who shall be, alas! her hope and protection, / And encourage her gifts, albethey weak? / Who shall attend her voice with such zeal? / Illumine her with such friendship and embrace her thus? / Hold her to his breast? O woe! O misfortune! / O unbearable lot for an innocent heart!]

These passages, and the poem as a whole, rehearse many topoi of the genres of lament (plach) and its more intimate and private counterpart, the elegy. Even so, they inventively - and as I have argued, characteristically for Petrov - couch both loss and yearning in a system of predication that once again ties the subject (both as lyric voice and as a unit of syntactic organization) to an other. Consider the tour-de-force "in my eyes your ( $v$ ochakh moikh tvoi) brilliant gaze (zrak) is still seen (zritsia)," a line in which the patron as the object of the poet's vision becomes the subject residing, through his spectral extension (gaze), in the poet, now a mere site or repository, or indeed reliquary. Even more intensely than in the coupling of the possessive pronouns (moikh tvoi), the reflexive verb "zritsia" welds together the agencies of poet and patron, the former doing the seeing, but even so ceding the position of subject. Returning once again to his signature imagery of enlivenment, Petrov associates the departed patron, eulogized as the poet's better half ( $s$ luchsheiu sebia rasstavshis' polovinoi), with life, and, conversely, his own life of bereavement with death, thereby one final time performing by now a purely symbolic exchange between poet and patron.

These ardent words are offered to Potemkin posthumously. Does this fact exonerate Petrov once and for all from charges of insincerity and opportunism? (As the poet himself argues, rather opportunistically.) What benefits could he in fact hope to reap from the deceased? This essay has sought to show that this question cannot be answered as readily as might be thought; that in answering it, we should look beyond the mere exchange of material goods between patron and poet, which reifies and hence purportedly cheapens the poet's offering. In fact, attendant on this very process of poetry's commodification, which is fueled by the institution of patronage and so routinely disparaged by the panegyric's critics, is an alternative, intratextual, economy of dependency. This is a grammar of patronage, both coordinating and subordinating, wherein patron, poet, and public emerge as lyric entities, and are defined and sustained

\footnotetext{
${ }^{57}$ Petrov, Sochineniia V. Petrova, 2: 105-15.
} 
through the discourses of relationship, commonality, and exchange. In this immanent poetic economy, the deceased patron still dispenses favors: the gift of enlivenment for the lyric voice. Petrov, even if only in order to defend his artistic credibility, cultivates a language for patronage as a phenomenon of inspiration in the lyric rather than purely social realm.

\section{Eloquence and Poetry: A Conclusion}

When not summarily dismissed as an apologist of Catherine and her courtiers, Petrov preserves in Russian literary history the reputation of a masterful, if also somewhat arcane, rhetorician, marked by a "rhetorical training of the ecclesiastical-scholastic type" (ritoricheskaia vyuchka tserkovno-knizhnogo tipa). ${ }^{58}$ Inasmuch as all panegyric speech belongs to the epideictic mode and intends to persuade its listeners, Petrov's panegyric verse can be read simply as some of the more overtly and complexly rhetorical of the odic production of the Russian eighteenth century. Is poetry, however, averse to rhetoric? Do we need to train different lenses on these two domains?

In his influential essay on poetic apostrophe, Jonathan Culler draws attention to the post-Enlightenment lyric as straining to repair, through the performative rhetorical act of the apostrophe, the weakened connection between subject and object, to regain or construct an addressee at whom lyric speech could be directed. ${ }^{59}$ Yet, even in addressing an other, the Romantic and post-Romantic lyric is continuously troubled by the difficulty, if not impossibility, of telling the $I$ and thou apart; of not knowing the would-be addressee as a priori a projection of the speaker's voice; of imagining a context in which poetic speech can transcend itself and find an interlocutor. ${ }^{60}$ Rhetoric, by contrast, is confident that this space of conversation, exchange, or interlocution in fact exists. This is the distinction between pre- and post-Enlightenment lyric that imbues Culler's argument about apostrophe with such poignancy precisely as an argument about the modern. This is also the distinction that lastingly informs our readings of poetic value, readings which, as posited at the beginning of this essay, have exempted Russian eighteenth-century lyric from aesthetic analysis. Though hardly preserving its purist clarity to this day, John Stuart Mill's famous dictum that "eloquence is heard; poetry is overheard" aptly describes the tendency to relegate pragmatics from the domain of poetics. ${ }^{61}$

Even in his most ingenious couplings of $I$ and thou, Petrov never loses sight of their ontological dividedness. In fact, the effect of these pairings, of their thrilling syntactic proximity, depends on the recognition of poet and patron not only as discrete, but also unequal personae. This is the basis of the peculiar construction of agency sans

\footnotetext{
${ }^{58}$ G. A. Gukovskii, "Petrov," in Istoriia russkoi literatury $v$ 10 t., ed. P. I. Lebedev-Polianskii (Moscow; Leningrad: Izdatel'stvo AN SSSR, 1947), 4:353-63, here 359.

${ }^{59}$ Jonathan Culler, "Apostrophe," in The Pursuit of Signs: Semiotics, Literature, Deconstruction (Ithaca: Cornell University Press, 2002), 135-54, here 143.

${ }^{60}$ Ibid., 148.

${ }^{61}$ John Stuart Mill, “Thoughts on Poetry and Its Varieties," The Crayon 7, no. 4 (April 1860): 93-97, here 95. This statement is also discussed by Culler, but in a somewhat different argument.
} 
autonomy in Petrov's texts. This, too, is the premise behind his lyric voice raised to articulate a relationship with its "better half." Might we not in conclusion propose the reliance upon an other - whether as muse or as reader, but in any case an other confidently placed both within and outside the text - as a crucial feature of the poetics of patronage, a feature that in fact enables us to argue for patronage as a poetics? 